\title{
Resource use and coexistence of two syntopic hylid frogs (Anura, Hylidae)
}

\author{
Marcelo Menin ${ }^{1,3}$, Denise de C. Rossa-Feres ${ }^{2} \&$ Ariovaldo A. Giaretta ${ }^{1}$ \\ 1 Instituto de Biologia, Universidade Federal de Uberlândia. 38400-902 Uberlândia, Minas Gerais, Brasil. \\ 2 Departamento de Zoologia e Botânica, Universidade Estadual Paulista. Rua Cristóvão Colombo 2265, 15054-000 São José \\ do Rio Preto, São Paulo, Brasil. \\ 3 Present address: Coordenação de Pesquisas em Ecologia, Instituto Nacional de Pesquisas da Amazônia. Avenida André \\ Araújo 2936, 69011-970 Manaus, Amazonas, Brasil. E-mail: menin@inpa.gov.br
}

\begin{abstract}
The objectives of this study were to measure and compare niche breadth and overlap of males of Hyla nana Boulenger, 1889 and Hyla sanborni Schmidt, 1944 in three neighboring ponds. The measured niche dimensions were seasonal occurrence, call site, and diet. The reproductive season of $H$. sanborni was longer in permanent ponds, whereas $H$. nana had a longer reproductive season in the temporary pond. Call site characteristics were similar for both species, however $H$. sanborni called from higher perches than $H$. nana. Diptera (Nematocera) were the most consumed item by both species in the three ponds but, in general, $H$. nana ingested larger prey than $H$. sanborni. For both species, the consumption of prey types was correlated with the availability in the environment. The multidimensional overlap between $H$. nana and $H$. sanborni was higher in the permanent ponds than the temporary pond, in which $H$. sanborni was rare. These species differed in abundance among ponds, consumed prey of different sizes, and probably fed in different time periods. Moreover, the data obtained suggest that structural differences in the ponds may modify the dynamics of resource partitioning between the two species. Beside the great overlap found in the major niche dimensions analyzed the detected differences may be great enough to allow their coexistence.
\end{abstract}

KEY WORDS. Hyla, multidimensional overlap, niche breadth, niche overlap, resource partitioning.

RESUMO. Uso de recursos e coexistência de duas espécies sintópicas de hilídeos (Anura, Hylidae). Os objetivos deste trabalho foram medir e comparar a amplitude e a sobreposição de nicho de Hyla nana e Hyla sanborni em três poças vizinhas. As dimensões de nicho medidas foram a ocorrência sazonal, o sítio de vocalização e a dieta, além da sobreposição multidimensional. Machos de $H$. nana são maiores que os de $H$. sanborni. A ocorrência sazonal de $H$. sanborni foi maior nos corpos d'água permanentes, enquanto $H$. nana apresentou maior período de ocorrência no corpo d'água temporário. $O$ sítio de vocalização foi similar para ambas as espécies; no entanto, H. sanborni ocupou poleiros mais altos do que H. nana. Diptera (Nematocera) foi o item mais consumido por ambas as espécies nos três corpos d'água, mas, em geral, $H$. nana consumiu presas maiores que $H$. sanborni. $O$ consumo de presas foi relacionado à sua disponibilidade no ambiente para ambas as espécies. A sobreposição multidimensional entre $H$. nana e $H$. sanborni foi mais alta nos corpos d'água permanentes do que no corpo d'água temporário, onde $H$. sanborni foi rara. Estas espécies ocorreram em abundâncias diferentes nos três corpos d'água, consumiram presas de tamanhos diferentes e provavelmente possuem diferença no período de alimentação. Além disso, os dados obtidos sugerem que diferenças estruturais nos corpos d'água podem modificar a dinâmica de partilha de recursos entre estas espécies. Apesar da grande sobreposição encontrada nos sítios de vocalização e categoria de presas ingeridas, diferenças detectadas em outras dimensões (ocorrência sazonal e volume de presas consumidas) podem ser suficientes para permitir a coexistência destas espécies.

PALAVRAS CHAVE. Amplitude de nicho, Hyla, partilha de recursos, sobreposição de nicho, sobreposição multidimensional.

The coexistence of similar species in ecological communities is one of the most perplexing problems in ecology (GoRDON 2000). The degree of overlap in resource use amongst co-occurring species is variable (BOWKer \& BOWKer 1979, ETGes 1987,
HeYer et al. 1990). In such a context, the 'position' of an organism within a community may be defined in terms of its patterns use of resources and its interaction with other organisms which use the same resources (PUTMan 1994). This abstraction 
of the position that an organism has within the community and its relationships with other organisms is expressed in the ecological niche concept (PuTman 1994). Major dimensions of niche are time, space and food (PIANKA 1994). The importance of these dimensions is variable, but generally the habitat dimension is often more important than the food-type dimension, which is often more important than the temporal dimension (Schoener 1974, Giller 1984). Ecological differences in each of these three dimensions may reduce competition and facilitate the coexistence of a variety of species (PIANKA 1975).

Differential use of space and time or food was described in several anuran communities and, in most of them, food (LimA \& Magnusson 1998) or microhabitat was the dimension that promoted the major segregation among species (CRUMP 1974, CARDOSo et al. 1989, Rossa-Feres \& JiM 1994). In closely related species of anurans, several mechanisms that promote coexistence were found: temporal segregation (BOWKER \& BOWKER 1979, Mac Nally 1985, Donnelly \& Guyer 1994), habitat segregation (Diaz \& Valencia 1985, Lizana et al. 1990) and call site segregation (Oldham \& Gerhardt 1975, Cardoso \& Vieldiard 1990).

Hyla nana Boulenger, 1889 and Hyla sanborni Schmidt, 1944 are two small, closely related hylid frogs (snout-vent length $20 \mathrm{~mm}$ ) included in the Hyla microcephala group and are very similar in morphology (LANGONE \& Basso 1987). They reproduce in temporary (RossA-Feres \& JIM 2001) and permanent (this study) ponds in open areas. In a temporary pond in the northwest of the state of São Paulo in southeastern Brazil, these species occur syntopically during the reproductive season (Rossa-Feres \& Jim 2001).

In order to understand the factors allowing the coexistence between these species, we determined the breadth and overlap of three major niche dimensions: space, time and diet for the two species.

\section{MATERIAL AND METHODS}

\section{Study area}

The study was carried out in three ponds on the Santo Antonio farm, district of Nova Itapirema, municipality of Nova Aliança $\left(21^{\circ} 11^{\prime} S, 49^{\circ} 42^{\prime} W\right)$, São Paulo State, Brazil: 1) PP: a permanent pond with Pontederiaceae, surface area of $50 \times 30$ $\mathrm{m}$, depth $0.60 \mathrm{~m}$, margins covered mainly with grasses (Poaceae and Cyperaceae) and Melastomataceae, Pontederiaceae and Typhaceae occurred in the water; 2) PG: a temporary pond surrounded by grasses (mean duration of hydroperiod seven months), surface area of $54 \times 22 \mathrm{~m}$, depth $0.70 \mathrm{~m}$, with aquatic vegetation composed by Poaceae, Cyperaceae and some Pontederiaceae; 3) PT: a permanent pond with Typhaceae, Poaceae and Cyperaceae, surface area of $20 \times 10 \mathrm{~m}$, depth 0.70 $\mathrm{m}$. The distance between PP and PG was $50 \mathrm{~m}, 100 \mathrm{~m}$ between PG and PT, and $120 \mathrm{~m}$ between PP and PT. The local climate is tropical seasonal (Cwa-Aw of Köppen), with a clearly defined rainy period (generally from October to March, but the rainfall may begin at any time between August and October) and dry season (April to September). Average temperatures are $22^{\circ} \mathrm{C}$ in the rainy season and $18^{\circ} \mathrm{C}$ in the dry season. The area receives $85 \%$ of the total annual rainfall during the rainy season (ARID \& BARCHA 1973).

The ponds were visited one day per month, from 6:00 to 11:00 p.m., during the rainy seasons of 1997/1998, 1999/2000 and 2000/2001, and weekly from July 1998 to June 1999. A total of 250 hours of fieldwork was performed during 50 visits to the ponds. The seasonal occurrence and call site of Hyla nana and Hyla sanborni were determined by the occurrence of calling males during each week period in 1998 and 1999. For the analysis of stomach contents, 135 males of Hyla nana (37, 62 and 36 individuals from PP, PG and PT, respectively) and 119 males of Hyla sanborni (50, 22 and 47 individuals) were collected.

The morphology of both species was characterized according to Duellman (1970) and Heyer et al. (1990) using snout-vent length (SVL), mouth width, interorbital distance, eye diameter, tibia length, thigh length, tarsus length, foot length and hand length. SVL was measured with calipers $(0.1 \mathrm{~mm})$ and the other dimensions were measured with a grid calibrated for the objective (nearest $0.01 \mathrm{~mm}$ ) of a stereomicroscope $(10 \mathrm{x})$. The SVL were compared by analysis of variance (ANOVA) (ZAR 1999).

Since the tadpoles, clutches or amplectant individuals were not searched, the presence of calling males indicate breeding activity. To determinate the total number of calling males for each visit, the ponds were searched along their perimeters, two hours after the beginning of the vocalizations and all males found visually or acoustically were counted; three or four of these were collected to analysis of stomach contents in each visit.

The call site was characterized by the following variables: type of substrate (Poaceae, Cyperaceae, Pontederiaceae, Typhaceae or Melastomataceae), position of individuals in relation to water surface (parallel, perpendicular up or down and diagonal), perch height on vegetation in relation to water surface and distance from the edge, towards the inner or outside of the pond. The perch height and distance from the edge were compared by Mann-Whitney U tests. Kruskal-Wallis tests (H) were used for comparisons among ponds. When the null hypothesis was rejected, a nonparametric multiple comparison test was applied to determine which of the samples had significant differences occurred (ZAR 1999).

Prey availability (arthropods) was quantified to compare with prey consumption through monthly samples performed along one edge of each pond. Arthropods were collected with a $30 \mathrm{~cm}$ diameter net, by sweeping in vegetation along $10 \mathrm{~m}$ (on the bank and over water) to right and left from each one of three points, which were separated from one another by $5 \mathrm{~m}$. The arthropods were preserved in 70\% alcohol.

In order to determine the diet of H. nana and H. sanborni, the calling males were caught, anesthetized and killed in $20 \%$ alcohol and fixed in $10 \%$ formalin. In the laboratory, the frogs were dissected and the stomach contents identified to order or 
family as indicated above. The length and width of each prey item were measured with calipers of $0.1 \mathrm{~mm}$ precision. When only fragments were found, they were compared with the specimens collected on the edge of the ponds for identification and inference of size. The volume of each prey was estimated using the spheroid volume formula (Colur et al. 1992): $\mathrm{V}=(\pi$. length. width $\left.{ }^{2}\right) / 6$.

The size (volume) of the prey consumed by H. nana and H. sanborni was compared by the test (ZAR 1999). The relation between the number of prey consumed and its availability in each pond was analyzed by the Spearman Correlation test $\left(\mathrm{r}_{\mathrm{s}}\right)$ (ZAR 1999). In order to determine differences in the frequency of prey types consumed by both species, the Chi-square test was used separately for each pond (ZAR 1999).

The temporal, spatial and trophic niche breadths were estimated for each species using the Shannon-Wiener index ( $H^{\prime}$, base 10, decits/individual) (KREBs 1999) and the values were compared by the t test (ZAR 1999). The niche overlap along each dimension was measured by the Morisita-Horn index $\left(C_{H}\right)$ (Krebs 1999). The multidimensional overlap was obtained by the arithmetic mean in each niche dimension, because the resource dimensions are interrelated (PutMan 1994).

Morphological and diet comparisons were made through Principal Components Analysis (PCA) (Digby \& Kempton 1987). The morphological data were log-transformed (base 10) prior to analysis (SOKAL \& Rohlf 1979). Because the species differed significantly in SVL, this trait was excluded from the PCA. For the diet analysis, the PCA was applied over the proportion of each type of prey. The significance level selected was 5\%, but values between 5 and 10\% were discussed as suggestive.

Collected arthropods and anurans were deposited at the Scientific Collection of the Department of Zoology and Botany, State University of São Paulo, São José do Rio Preto campus (DZSJRP), and in the Anuran Collection at the Museu de Biodiversidade do Cerrado (AAG-UFU 2253-2270), Uberlândia Federal University (UFU), Minas Gerais State, Brazil.

\section{RESULTS}

\section{Morphological traits}

The males of H. nana (Hn) had a mean SVL of $19.8 \mathrm{~mm}$ $( \pm 1.0 ; \mathrm{n}=10$; range: $17.9-21.2 \mathrm{~mm})$ and were larger $(\mathrm{F}=67.6$; $\mathrm{df}=18 ; \mathrm{p}<0.01)$ than those of the $H$. sanborni $(\mathrm{Hs})(\mathrm{SVL}=16.4$ $\mathrm{mm} \pm 0.8 ; \mathrm{n}=10$; range: $15.3-17.7 \mathrm{~mm}$ ). The PCA showed that size is an important characteristic that contributed to differentiation of species, the first and second principal component accounted for $90.7 \%$ and $3.3 \%$, respectively, of the variation among species (Fig. 1).

\section{Seasonal occurrence}

Hyla sanborni began its reproductive season in August and its abundance was relatively stable throughout the rainy season in PP and PT in comparison to H. nana. However, $H$. sanborni was rare in PG (one individual in August, one in Sep-

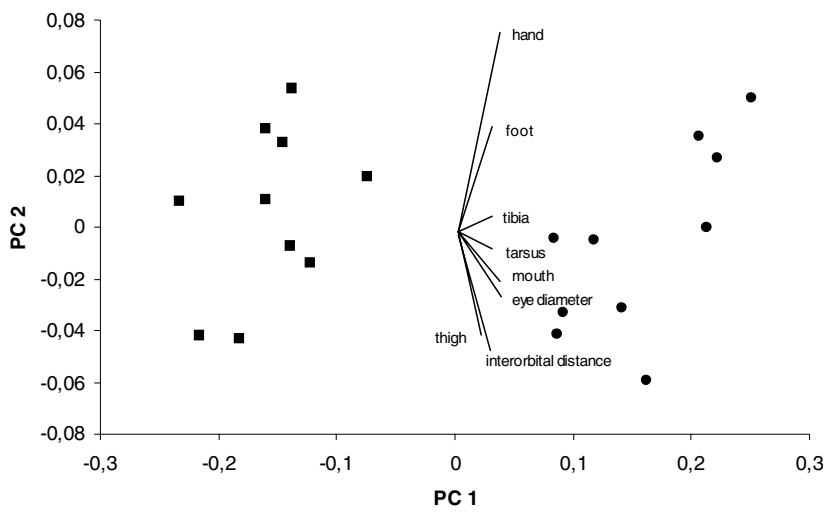

Figure 1. Morphological characterization of the males of $H$. nana (circles) and $H$. sanborni (squares), at the Nova Itapirema, northwestern São Paulo, Brazil, based on the first two principal components.

tember and two in January) (Fig. 2). Hyla nana began its reproductive season in August in PG and in September at PP and PT, with peaks of abundance in October, November and December (Fig. 2). Hyla nana was most abundant in the PG, where it began its reproductive season in August. At PP and PT, H. sanbor$n i$ was more abundant at the beginning of the rainy season, but $H$. nana was more abundant in the middle of season (Fig. 2). The values of the temporal niche breadth were higher in $H$. sanborni than in H. nana in PP and PT (Tab. I).

\section{Call site}

At PP, the males of $H$. nana and $H$. sanborni called mostly on Pontederiaceae (46 and 38\% respectively), in a position parallel to the water surface ( 42 and $50 \%$ respectively). Males of $H$. sanborni called further from the edge of the water than males of $H$. nana (mean Hs $=188.1 \mathrm{~cm}$, mean $\mathrm{Hn}=147.1 \mathrm{~cm}$, Mann-Whitney U test $=608.0, \mathrm{p}<0.05$, Tab. II). Generally, there was no difference in call site niche breadths between these species (Tabs I and II).

Males of H. sanborni were rare $(n=4)$ at PG and called on different substrates and on higher perches than $H$. nana (mean $\mathrm{Hs}=43.3 \mathrm{~cm}$, mean $\mathrm{Hn}=20.1 \mathrm{~cm}$, Mann-Whitney $\mathrm{U}$ test $=$ $14.5, \mathrm{p}<0.01$, Tab. II). The majority of males of $H$. nana called on leaves of Poaceae (55\%), in a position parallel to the water surface (65\%). There was no difference between these two species regarding niche breadth for type, position on substrate of call sites (Tab. I).

At PT, the males of $H$. nana and $H$. sanborni called mostly on Typhaceae (75 and 93\% respectively), perpendicular to the water surface, oriented towards the water (54 and 53\% respectively). There were no difference for height of the call site and the distance from the edge of the water (Tab. II). For type of substrate, $H$. nana had a larger niche breadth (Tab. I).

The calling height of $H$. nana differed among ponds $(\mathrm{H}=$ $84.8, \mathrm{p}<0.001)$; the mean height of the call sites was signifi-

Revista Brasileira de Zoologia 22 (1): 61-72, março 2005 

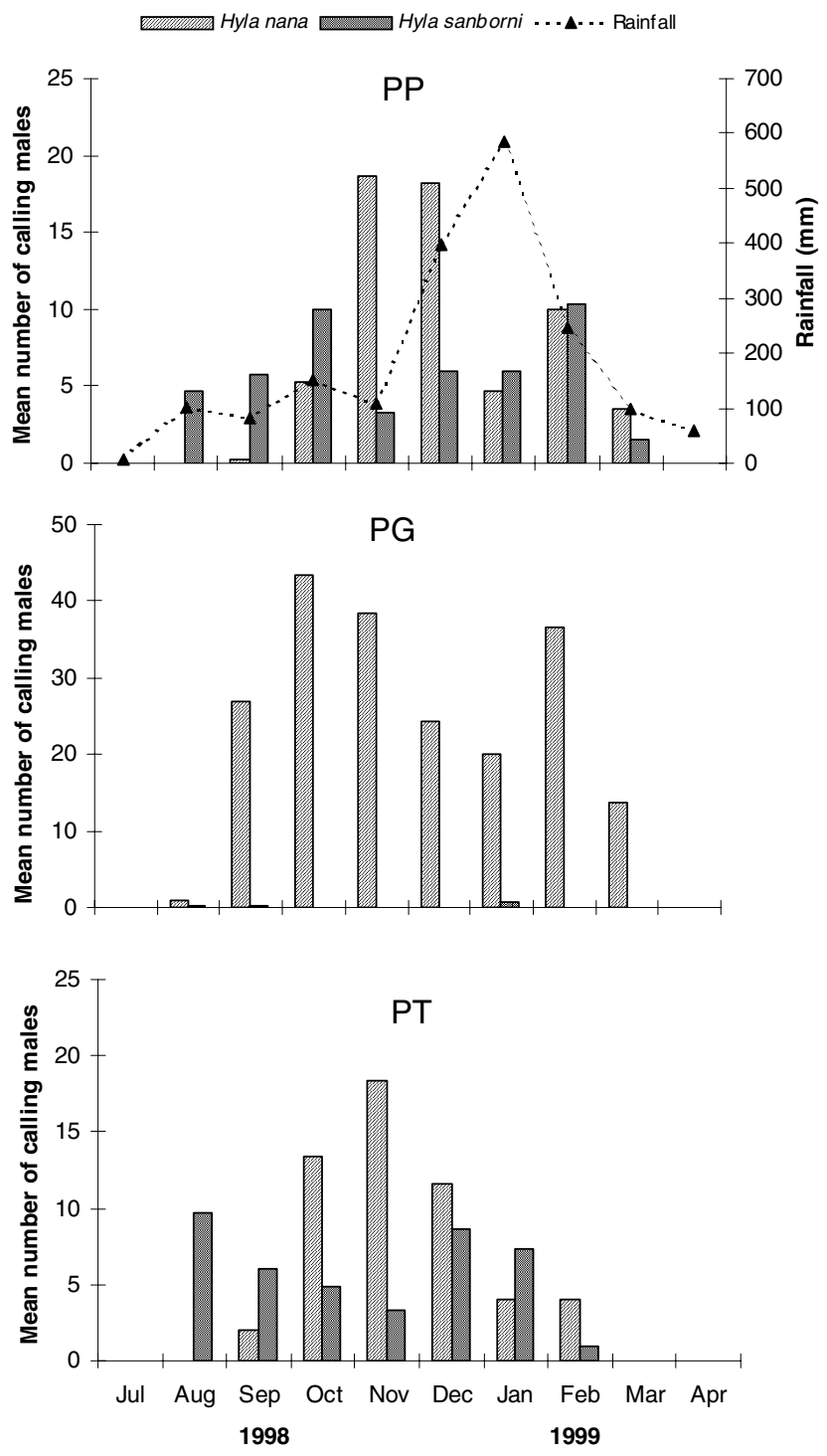

Figure 2. Monthly abundance of calling males of Hyla nana and Hyla sanborni at three ponds (PP, PG and PT), Nova Itapirema, northwestern São Paulo, Brazil, and monthly rainfall in period from July 1998 to April 1999.

cantly lower in PG than PP and PT. There was no difference in the distance from the edge $(\mathrm{H}=1.7, \mathrm{p}>0.10)$. Hyla sanborni had an inverse pattern: the height of the call site tended to differ among ponds $(\mathrm{H}=4.7, \mathrm{p}<0.10)$, and the distance from edge differed significantly $(\mathrm{H}=6.1, \mathrm{p}<0.05)$; the distance from the edge was significantly farther in PP than PG and PT.

\section{Diet}

One hundred and two taxa (orders and families) of arthropods were identified at the three ponds. Forty of them were consumed by $H$. nana and $H$. sanborni.
Hyla sanborni had a larger number of empty stomachs (72, 48 and 66\%) than H. nana (40, 48 and 36\%) at PP, PG, and PT, respectively.

At the order level, both species consumed mostly Diptera, although $H$. nana had consumed a larger amount of this item than H. sanborni at PT and the inverse had occurred at PP (Tab. III).

Hyla nana consumed arthropods that were frequent and also those that were ephemeral, such as winged Isoptera. Hyla sanborni had a less diversified diet, consuming prey that as more abundant in the ponds studied (Tabs IV, V and VI). Hyla nana ingested prey with larger volumes than $H$. sanborni $(\mathrm{t}=2.00$; $\mathrm{df}$ $=243 ; \mathrm{p}<0.05)$. Nematocera was the most frequently consumed prey type of both species at the three ponds.

The dimensions of trophic niche of $H$. nana and $H$. sanborni were similar at PP (Tab. I). Hyla nana consumed mostly Nematocera, Araneae and Formicidae, but the most important item by volume was Blattariae. The most important item by volume was Cicadellidae for $H$. sanborni (Tab. IV). The consumption of prey and its availability were positively correlated for $H$. nana $\left(\mathrm{r}_{\mathrm{s}}=0.84, \mathrm{n}=14, \mathrm{p}<0.01\right)$ and for $H$. sanborni $\left(\mathrm{r}_{\mathrm{s}}=\right.$ 0.90, $\mathrm{n}=12, \mathrm{p}<0.01)$.

At PG, H. nana had a larger niche breadth for prey types and volume (Tab. I). Both species consumed mostly Nematocera and Cicadellidae, but the most important items by volume were Isoptera and Cicadellidae for $H$. nana and Alleculidae for $H$. sanborni (Tab. V). The consumption of prey and its availability were positively correlated for $H$. nana $\left(\mathrm{r}_{\mathrm{s}}=0.58 ; \mathrm{n}=22, \mathrm{p}<0.01\right)$ and for H. sanborni $\left(\mathrm{r}_{\mathrm{s}}=0.79, \mathrm{n}=8 ; \mathrm{p}<0.05\right)$ at this site.

At PT, $H$. nana had a larger niche breadth for number of prey by category and volume of prey (Tab. I). Hyla nana consumed mostly Nematocera and Formicidae, but the most important items by volume were unidentified Diptera and Coleoptera. Hyla sanborni consumed mostly Nematocera. This item was the most important in volume (Tab. VI). The consumption of prey and its availability were not correlated for $H$. nana $\left(\mathrm{r}_{\mathrm{s}}=0.19, \mathrm{n}=\right.$ 20, $\mathrm{p}>0.10)$, and for H. sanborni $\left(\mathrm{r}_{\mathrm{s}}=0.52, \mathrm{n}=9, \mathrm{p}<0.10\right)$.

The PCA demonstrated differences in diet related to species and environments. The first and second main components accounted for $34.7 \%$ and $27.5 \%$ of the variation, respectively. The most important variables in the first principal component were Drosophilidae, Tipulidae, Curculionidae, Cecidomyiidae, Trichoptera, Psocoptera, Tettigoniidae and unidentified Diptera, Hymenoptera and Coleoptera, on the positive side (which contains H. nana at PG and PT) and Chloropidae and Cicadellidae on the negative side (that contains $H$. nana at PP and H. sanborni of the three ponds) (Tab. VII and Fig. 3). In the second principal component, the most important variables were Chloropidae, Others Nematocera and Collembola on the positive side, which contains $H$. sanborni from the three ponds and $H$. nana from PP and PT (Tab. VII and Fig. 3). The diet of $H$. nana differed among the ponds, as shown by the greater point dispersion of H. nana in the food space (Fig. 3). 
Table I. Niche breadths $\left(\mathrm{H}^{\prime}\right)$ of Hyla nana $(\mathrm{Hn})$ and Hyla sanborni (Hs), at three ponds (PP, PG and PT), Nova Itapirema, northwestern São Paulo, Brazil. (NS) difference not significant: $p>0.05$.

\begin{tabular}{|c|c|c|c|c|c|c|c|c|c|c|c|c|c|c|c|}
\hline \multirow{2}{*}{ Niche Dimensions } & \multicolumn{5}{|c|}{$\mathrm{PP}$} & \multicolumn{5}{|c|}{ PG } & \multicolumn{5}{|c|}{ PT } \\
\hline & $\mathrm{Hn}$ & $\mathrm{Hs}$ & $\mathrm{t}$ & gl & $p$ & $\mathrm{Hn}$ & $\mathrm{Hs}$ & $\mathrm{t}$ & $\mathrm{gl}$ & $p$ & $\mathrm{Hn}$ & Hs & $\mathrm{t}$ & $\mathrm{gl}$ & $p$ \\
\hline Reproductive season & 0.69 & 0.84 & -5.50 & 321 & $<0.01$ & 0.81 & 0.45 & 4.79 & 4 & $<0.01$ & 0.69 & 0.78 & -3.46 & 297 & $<0.01$ \\
\hline \multicolumn{16}{|l|}{ Call site } \\
\hline Perch Height & 0.77 & 0.78 & -0.10 & 81 & NS & 0.62 & 0.28 & 3.97 & 4 & $<0.05$ & 0.88 & 0.86 & 0.28 & 93 & NS \\
\hline Distance from edge & 0.77 & 0.80 & -0.49 & 79 & NS & 0.87 & 0.48 & 27.37 & 105 & $<0.01$ & 0.78 & 0.65 & 2.82 & 82 & $<0.01$ \\
\hline Type of substrate & 0.61 & 0.57 & 0.59 & 79 & NS & 0.51 & 0.48 & 16.69 & 118 & NS & 0.37 & 0.13 & 2.93 & 92 & $<0.01$ \\
\hline Position on substrate & 0.54 & 0.47 & 1.36 & 83 & NS & 0.37 & 0.28 & 1.06 & 4 & NS & 0.48 & 0.46 & 0.37 & 100 & NS \\
\hline \multicolumn{16}{|l|}{ Diet } \\
\hline Types of prey & 1.05 & 0.94 & 1.23 & 49 & NS & 1.17 & 0.59 & 4.93 & 51 & $<0.01$ & 1.01 & 0.65 & 3.23 & 63 & $<0.01$ \\
\hline Volume of prey & 0.70 & 0.73 & -0.46 & 216 & NS & 1.06 & 0.52 & 8.17 & 39 & $<0.01$ & 1.06 & 0.77 & 5.44 & 83 & $<0.01$ \\
\hline
\end{tabular}

Table II. Mean perch height ( $\mathrm{cm} \pm 1 \mathrm{SD}$ ) and distance from the water's edge of calling males of Hyla nana (Hn) and Hyla sanborni (Hs), at three ponds (PP, PG e PT), Nova Itapirema, northwestern São Paulo, Brazil. (N) Sample size, $\left(^{*}\right)$ significant difference: $p<0.05$.

\begin{tabular}{|c|c|c|c|c|c|c|}
\hline & \multicolumn{2}{|c|}{$\mathrm{PP}$} & \multicolumn{2}{|c|}{ PG } & \multicolumn{2}{|c|}{ PT } \\
\hline & $\mathrm{Hn}$ & $\mathrm{Hs}$ & $\mathrm{Hn}$ & Hs & $\mathrm{Hn}$ & $\mathrm{Hs}$ \\
\hline Perch height & $41.4 \pm 15.3$ & $47.1 \pm 19.6$ & $* 20.1 \pm 12.0$ & $* 43.3 \pm 5.8$ & $50.6 \pm 23.6$ & $54.2 \pm 19.7$ \\
\hline $\mathrm{N}$ & 39 & 49 & 116 & 3 & 49 & 54 \\
\hline Distance from edge & *147.1 \pm 84.1 & *188.1 \pm 107.7 & $151.7 \pm 135.3$ & $163.3 \pm 105.0$ & $159.9 \pm 91.2$ & $150.9 \pm 57.5$ \\
\hline $\mathrm{N}$ & 38 & 43 & 105 & 3 & 45 & 50 \\
\hline
\end{tabular}

Table III. Frequency of the most important prey (orders) in diets of H. nana and H. sanborni, in the three ponds (PP, PG e PT), Nova Itapirema, northwestern São Paulo, Brazil. (*) significant difference.

\begin{tabular}{lrrrr}
\hline \multirow{2}{*}{$\begin{array}{c}\text { Pond } \\
\text { Category of prey }\end{array}$} & \multicolumn{4}{c}{ Frequency (\%) } \\
\cline { 2 - 5 } & H. nana & H. sanborni & \multicolumn{1}{c}{$\chi^{2}$} & $\mathrm{p}$ \\
\hline PP & & & & \\
Diptera & 45.45 & 78.57 & $* 3.86$ & 0.05 \\
Araneae & 18.18 & 14.28 & 0.09 & 0.76 \\
Homoptera & 22.72 & 35.71 & 0.72 & 0.40 \\
PG & & & & \\
Acari & 6.25 & 9.09 & 0.10 & 0.75 \\
Coleoptera & 15.62 & 9.09 & 0.29 & 0.59 \\
Collembola & 12.50 & 18.18 & 0.22 & 0.64 \\
Diptera & 46.87 & 63.63 & 0.92 & 0.34 \\
Homoptera & 28.12 & 27.27 & 0.01 & 0.96 \\
Hymenoptera & 9.37 & 18.18 & 0.62 & 0.43 \\
PT & & & & \\
Collembola & 13.04 & 18.75 & 0.24 & 0.63 \\
Diptera & 86.95 & 56.25 & $* 4.67$ & 0.03 \\
Homoptera & 13.04 & 18.75 & 0.24 & 0.63 \\
\hline
\end{tabular}

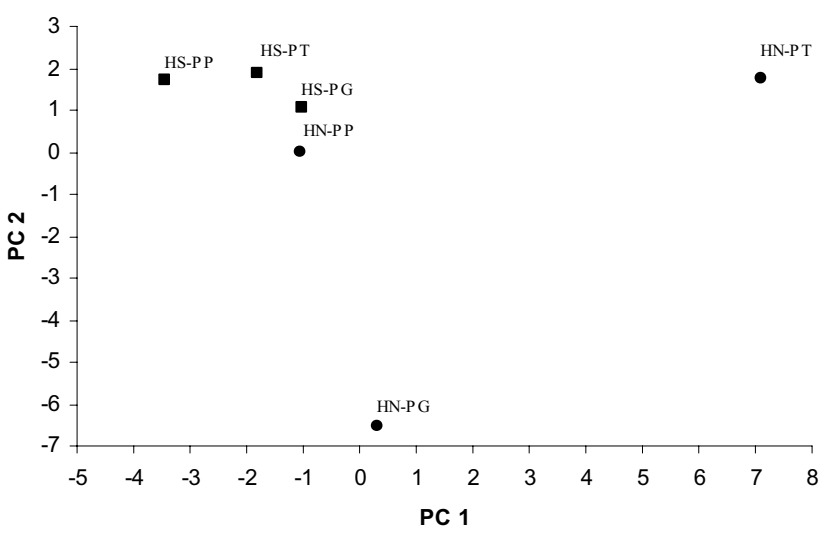

Figure 3. Characterization of the diet of $\mathrm{H}$. nana $(\mathrm{HN})$ and $\mathrm{H}$. sanborni (HS), at three ponds (PP, PG and PT), Nova Itapirema, northwestern São Paulo, Brazil, based on the first two principal components.

$\mathrm{N}$ iche overlap

The niche overlap between $\mathrm{H}$. nana and $\mathrm{H}$. sanborni in the call site and types of prey was wide among the three ponds (Tab. VIII). The overlap in prey was low because H. nana consumed items with larger volume than $\mathrm{H}$. sanborni. At PG, the 
Table IV. Prey availability (A), number, volume and frequency in stomachs of prey taxa in the diet of $H$. nana and $H$. sanborni at PP, Nova Itapirema, northwestern São Paulo, Brazil. $\mathrm{N}=22$ stomachs to $\mathrm{H}$. nana and 14 to $\mathrm{H}$. sanborni. $\mathrm{N}=2212$ individual prey in the sample of prey availability.

\begin{tabular}{|c|c|c|c|c|c|c|c|}
\hline \multirow{2}{*}{ Category of prey } & \multirow[b]{2}{*}{ A (\%) } & \multicolumn{3}{|c|}{ Hyla nana } & \multicolumn{3}{|c|}{ Hyla sanborni } \\
\hline & & Number & Vol.(\%) & Freq. (\%) & Number & Vol.(\%) & Freq.(\%) \\
\hline Acari & 3.30 & 2 & 0.04 & 4.54 & - & - & - \\
\hline Araneae & 4.11 & 5 & 3.46 & 18.18 & 2 & 2.34 & 14.28 \\
\hline Blattariae & 1.04 & 1 & 56.27 & 4.54 & - & - & - \\
\hline Collembola & 3.80 & - & - & - & 2 & 0.03 & 14.28 \\
\hline \multicolumn{8}{|l|}{ Diptera } \\
\hline Chloropidae & 8.14 & 3 & 7.22 & 13.63 & 3 & 15.85 & 21.42 \\
\hline Ephydridae & - & - & - & - & 1 & 6.57 & 7.14 \\
\hline Neriidae & - & - & - & - & 1 & 11.68 & 7.14 \\
\hline Unidentified Nematocera & 25.23 & 5 & 1.53 & 22.72 & 8 & 7.30 & 35.71 \\
\hline Unidentified & 0.14 & 2 & 3.93 & 9.09 & 1 & 0.22 & 7.14 \\
\hline \multicolumn{8}{|l|}{ Hemiptera } \\
\hline Pyrrhocoridae & 0.05 & 1 & 0.56 & 4.54 & - & - & - \\
\hline \multicolumn{8}{|l|}{ Homoptera } \\
\hline Aphididae & 0.10 & 1 & 0.56 & 4.54 & 1 & 0.36 & 7.14 \\
\hline Cicadellidae & 21.61 & 2 & 4.49 & 9.09 & 4 & 43.54 & 21.42 \\
\hline Flatidae & 0.05 & 1 & 2.53 & 4.54 & - & - & - \\
\hline Unidentified & 0.05 & 1 & 3.75 & 4.54 & 1 & 11.68 & 7.14 \\
\hline \multicolumn{8}{|l|}{ Hymenoptera } \\
\hline Formicidae & 5.15 & 5 & 3.75 & 18.18 & - & - & - \\
\hline Isoptera & - & 1 & 11.81 & 4.54 & - & - & - \\
\hline Thysanoptera & - & - & - & - & 1 & 0.08 & 7.14 \\
\hline Unidentified Insects & - & 1 & 0.04 & 4.54 & 1 & 0.01 & 7.14 \\
\hline Other & 27.23 & & & & & & \\
\hline Total & & 31 & & & 26 & & \\
\hline
\end{tabular}

overlap in reproductive season was low. The multidimensional overlap was larger in the PP and PT, and lower at PG where $H$. sanborni was rare (Tab. VIII).

\section{DISCUSSION}

\section{Seasonal occurrence}

Hyla nana and Hyla sanborni are morphologically very similar species and they occur in sympatry in some sites in Argentina, Paraguay and Brazil (Langone \& Basso 1987). They are different in size (this study), and structure of advertisement call (Basso et al. 1985, Rossa-Feres \& Jim 2001, Martins \& Jim 2003).

In the northwestern region of the state of São Paulo, these two species overlapped in seasonal occurrence at PP and PT, which coincided with the rainy season. The small overlap at PG resulted from the rarity of $H$. sanborni at this site. In tropical regions with seasonal climate, the majority of anuran spe- cies reproduce during the rainy season (AICHINGER 1987, RossAFeres \& JiM 1994, POMBAL Jr. 1997). Hyla sanborni was more abundant and had a more prolonged reproductive period in permanent ponds, while $H$. nana was more abundant in the temporary pond, as verified by Rossa-Feres \& JIM (2001). At the southeastern region in the state of São Paulo, H. sanborni calls from the end of dry season until the end of the wet season (RossaFeres \& Jim 1994). The shorter and the annual variability in the reproductive period of $H$. sanborni in the northwestern region is probably a consequence of the pronounced dry season and of the unpredictability of the climate, because the rainfall may begin at any time between August and October depending on the year. Among closely related species of anurans, different patterns of reproductive periods have been found; some species presented broad overlap in temporal niche (OLDHAM \& Gerhardt 1975, Lizana et al. 1990, Donnelly \& Guyer 1994) while others were found to have a small overlap (BOWKER \& BOWKER 1979, Diaz \& Valencia 1985, Mac Nally 1985). 
Table V. Prey availability (A), number, volume and frequency in stomachs of prey taxa in the diet of $H$. nana and $H$. sanborni at PG, Nova Itapirema, northwestern São Paulo, Brazil. $\mathrm{N}=32$ stomachs to $H$. nana and 11 to $H$. sanborni. $\mathrm{N}=1912$ individual prey in the sample of prey availability.

\begin{tabular}{|c|c|c|c|c|c|c|c|}
\hline \multirow{2}{*}{ Category of prey } & \multirow{2}{*}{$A(\%)$} & \multicolumn{3}{|c|}{ Hyla nana } & \multicolumn{3}{|c|}{ Hyla sanborni } \\
\hline & & Number & Vol. (\%) & Freq. (\%) & Number & Vol. (\%) & Freq. (\%) \\
\hline Acari & 5.20 & 2 & 0.05 & 6.25 & 1 & 0.02 & 9.09 \\
\hline Araneae & 3.40 & 4 & 7.40 & 9.37 & - & - & - \\
\hline \multicolumn{8}{|l|}{ Coleoptera } \\
\hline Alleculidae & - & - & - & - & 1 & 55.05 & 9.09 \\
\hline Chrysomelidae & 0.20 & 1 & 0.38 & 3.12 & - & - & - \\
\hline Cleridae & 0.10 & 2 & 8.39 & 6.25 & - & - & - \\
\hline Erotylidae & 0.70 & 1 & 6.89 & 3.12 & - & - & - \\
\hline Silphidae & 0.10 & 1 & 5.74 & 3.12 & - & - & - \\
\hline Collembola & 10.10 & 4 & 0.13 & 12.50 & 2 & 0.43 & 18.18 \\
\hline \multicolumn{8}{|l|}{ Diptera } \\
\hline Drosophilidae & 1.10 & 2 & 0.70 & 6.25 & - & - & - \\
\hline Muscidae & 0.40 & 1 & 3.57 & 3.12 & - & - & - \\
\hline Tipulidae & 0.50 & 1 & 0.38 & 3.12 & - & - & - \\
\hline Unidentified Nematocera & 18.00 & 25 & 2.08 & 28.12 & 17 & 11.18 & 63.63 \\
\hline Unidentified & 0.30 & 2 & 0.27 & 6.25 & - & - & - \\
\hline \multicolumn{8}{|l|}{ Hemiptera } \\
\hline Lygaeidae & 0.20 & 1 & 1.43 & 3.12 & - & - & - \\
\hline \multicolumn{8}{|l|}{ Homoptera } \\
\hline Aphididae & - & 2 & 0.30 & 6.25 & 1 & 1.95 & 9.09 \\
\hline Cercopidae & - & 1 & 1.14 & 3.12 & - & - & - \\
\hline Cicadellidae & 23.40 & 7 & 18.08 & 15.62 & 2 & 25.84 & 18.18 \\
\hline Delphacidae & 0.90 & 1 & 0.04 & 3.12 & - & - & - \\
\hline \multicolumn{8}{|l|}{ Hymenoptera } \\
\hline Formicidae & 3.80 & 3 & 7.75 & 9.37 & 2 & 5.34 & 18.18 \\
\hline Isoptera & - & 2 & 18.25 & 6.25 & - & - & - \\
\hline Odonata & - & 1 & 5.10 & 3.12 & - & - & - \\
\hline \multicolumn{8}{|l|}{ Orthoptera } \\
\hline Gryllidae & 2.50 & 2 & 10.62 & 6.25 & - & - & - \\
\hline Unidentified Insects & 0.10 & 2 & 1.21 & 6.25 & 1 & 0.14 & 9.09 \\
\hline Other & 29.00 & & & & & & \\
\hline Total & & 68 & & & 27 & & \\
\hline
\end{tabular}

\section{Call site}

Males of H. nana and H. sanborni called from the same type of substrate, adopting the same position in calling perch in each pond, which resulted in wide overlap in spatial niche. Despite the fact that the perch height did not differ significantly in the PP and PT, the mean perch height of H. sanborni at the three ponds was higher than H. nana, as verified by RossaFeres \& Jim (2001) at PG. At PP, the size and the hydroperiod of the pond seemed to have allowed the exploitation of different substrates by $H$. sanborni, because the aquatic vegetation is available before the beginning of the rainy season. The later occurrence of H. sanborni at PG and its large abundance in permanent ponds, may be related to the physical structure of the vegetation, because this species perches in higher places in vegetation. On other hand, $H$. nana perched in lower sites at PG, because the aquatic vegetation, growing only after the beginning of the rainy season, is composed only by grasses and determines a lower environmental heterogeneity.

Mac Nally (1985) and Donnelly \& Guyer (1994) verified a wide overlap in call site for closely related species. According 
Table VI. Prey availability (A), number, volume and frequency in stomachs of prey taxa in the diet of $H$. nana and $H$. sanborni at PT, Nova Itapirema, northwestern São Paulo, Brazil. $N=23$ stomachs to $H$. nana and 16 to $H$. sanborni. $N=1833$ individual prey in the sample of prey availability.

\begin{tabular}{|c|c|c|c|c|c|c|c|}
\hline \multirow{2}{*}{ Category of prey } & \multirow{2}{*}{$\mathrm{A}(\%)$} & \multicolumn{3}{|c|}{ Hyla nana } & \multicolumn{3}{|c|}{ Hyla sanborni } \\
\hline & & Number & Vol. (\%) & Freq. (\%) & Number & Vol. (\%) & Freq. (\%) \\
\hline Acari & 11.13 & 3 & 0.07 & 13.04 & - & - & - \\
\hline Araneae & 6.23 & 1 & 7.22 & 4.35 & 1 & 3.98 & 6.25 \\
\hline \multicolumn{8}{|l|}{ Coleoptera } \\
\hline Curculionidae & - & 2 & 4.28 & 8.69 & - & - & - \\
\hline Unidentified & - & 1 & 16.27 & 4.35 & - & - & - \\
\hline Collembola & 12.77 & 3 & 0.35 & 13.04 & 3 & 0.50 & 18.75 \\
\hline \multicolumn{8}{|l|}{ Diptera } \\
\hline Cecidomyiidae & 1.58 & 2 & 0.43 & 8.69 & - & - & - \\
\hline Chloropidae & 2.35 & - & - & - & 1 & 11.94 & 6.25 \\
\hline Drosophilidae & 1.96 & 1 & 3.70 & 4.35 & - & - & - \\
\hline Psychodidae & 0.38 & - & - & - & 1 & 0.05 & 6.25 \\
\hline Tipulidae & 0.11 & 2 & 6.23 & 8.69 & - & - & - \\
\hline Unidentified Nematocera & 15.06 & 23 & 6.27 & 52.17 & 18 & 29.26 & 43.75 \\
\hline Unidentified & 0.11 & 4 & 22.41 & 13.04 & - & - & - \\
\hline \multicolumn{8}{|l|}{ Hemiptera } \\
\hline Lygaeidae & 0.49 & 1 & 3.66 & 4.35 & 1 & 3.98 & 6.25 \\
\hline \multicolumn{8}{|l|}{ Homoptera } \\
\hline Aphididae & 0.05 & 2 & 1.19 & 8.69 & - & - & - \\
\hline Cercopidae & 0.05 & - & - & - & 1 & 11.94 & 6.25 \\
\hline Cicadellidae & 15.00 & 1 & 0.72 & 4.35 & 2 & 15.44 & 12.50 \\
\hline \multicolumn{8}{|l|}{ Hymenoptera } \\
\hline Formicidae & 4.14 & 9 & 10.74 & 21.74 & - & - & - \\
\hline Unidentified & - & 1 & 0.18 & 4.35 & - & - & - \\
\hline Isoptera & - & 2 & 3.61 & 4.35 & - & - & - \\
\hline \multicolumn{8}{|l|}{ Orthoptera } \\
\hline Tettigoniidae & 0.71 & 1 & 7.23 & 4.35 & - & - & - \\
\hline Psocoptera & 0.54 & 1 & 0.26 & 4.35 & - & - & - \\
\hline Trichoptera & 0.11 & 1 & 4.07 & 4.35 & - & - & - \\
\hline Unidentified Insects & 0.05 & 1 & 1.08 & 4.35 & 3 & 22.89 & 12.50 \\
\hline Other & 27.18 & & & & & & \\
\hline Total & & 62 & & & 31 & & \\
\hline
\end{tabular}

to Heyer et al. (1990), the habitat type seems to be an evolutionarily conservative trait among closely related species. However, the call site partition (BOWKer \& BOWKER 1979, ETGEs 1987) or microhabitat partition (LOMAN 1978, Diaz \& VALENCIA 1985, HeYer et al. 1990, LizANa et al. 1990) seems to be common in anurans. In sympatric species of Rana, the structural aspects of vegetation were an important feature of discrimination of microhabitat (McAlpine \& Dilworth 1989). Besides that, species with wide overlap in call site present small overlap in the structure of call (Duellman \& Pyles 1983, Rossa-Feres \& Jim 2001), which is the most important mechanism of reproductive isolation between co-occurring species (HöDL 1977, CRUMP 1982). Diet

The two species were diet generalists, consuming prey types in proportion to their abundance in the environment, including ephemeral resources, such as winged termites, which reinforces the idea that anurans are opportunists (LABANICK 1976). A major difference between the diets of both species was the consumption of Araneae, Formicidae and Cicadellidae in abundance by $H$. nana, while $H$. sanborni ingested only 
Table VII. Eingenvalues of prey items for the first two principal components (PC) of $H$. nana and $H$. sanborni in the three ponds (PP, PG and PT), Nova Itapirema, northwestern São Paulo, Brazil.

\begin{tabular}{|c|c|c|}
\hline Category of prey & PC 1 & PC 2 \\
\hline Acari & 0.234 & -0.118 \\
\hline Araneae & 0.177 & -0.154 \\
\hline Blatariae & -0.038 & 0.001 \\
\hline \multicolumn{3}{|l|}{ Coleoptera } \\
\hline Alleculidae & -0.037 & 0.049 \\
\hline Cleridae & 0.011 & -0.298 \\
\hline Chrysomelidae & 0.011 & -0.298 \\
\hline Curculionidae & 0.256 & 0.081 \\
\hline Erotylidae & 0.011 & -0.298 \\
\hline Silphidae & 0.011 & -0.298 \\
\hline Unidentified Coleoptera & 0.256 & 0.081 \\
\hline Collembola & 0.073 & 0.108 \\
\hline \multicolumn{3}{|l|}{ Diptera } \\
\hline Cecidomyiidae & 0.256 & 0.081 \\
\hline Chloropidae & -0.179 & 0.136 \\
\hline Drosophilidae & 0.263 & 0.025 \\
\hline Ephydridae & -0.125 & 0.080 \\
\hline Muscidae & 0.011 & -0.298 \\
\hline Nematocera & -0.067 & 0.142 \\
\hline Neriidae & -0.125 & 0.080 \\
\hline Psychodidae & 0.256 & 0.081 \\
\hline Tipulidae & 0.259 & 0.064 \\
\hline Unidentified Diptera & 0.255 & 0.081 \\
\hline \multicolumn{3}{|l|}{ Hemiptera } \\
\hline Lygaeidae & 0.150 & 0.048 \\
\hline Pyrrhocoridae & -0.038 & 0.001 \\
\hline \multicolumn{3}{|l|}{ Homoptera } \\
\hline Aphididae & 0.096 & 0.075 \\
\hline Cercopidae & -0.066 & 0.060 \\
\hline Cicadellidae & -0.190 & 0.020 \\
\hline Delphacidae & 0.011 & -0.298 \\
\hline Flatidae & -0.038 & 0.001 \\
\hline Unidentified Homoptera & -0.139 & 0.081 \\
\hline \multicolumn{3}{|l|}{ Hymenoptera } \\
\hline Formicidae & 0.238 & -0.112 \\
\hline Unidentified Hymenoptera & 0.256 & 0.081 \\
\hline Isoptera & 0.035 & -0.272 \\
\hline Odonata & 0.011 & -0.298 \\
\hline \multicolumn{3}{|l|}{ Orthoptera } \\
\hline Gryllidae & 0.011 & -0.298 \\
\hline Tettigoniidae & 0.256 & 0.081 \\
\hline Psocoptera & -0.066 & 0.088 \\
\hline Trichoptera & 0.256 & 0.081 \\
\hline Tysanoptera & -0.125 & 0.080 \\
\hline Unidentified Insecta & -0.055 & 0.078 \\
\hline
\end{tabular}

Nematocera in abundance. In Argentina, H. nana consumed preponderantly Diptera (Basso 1990), Formicidae and Araneae (Peltzer \& Lajmanovich 2000), indicating a strong environmental influence in the diet of this species. Hyla sanborni consumed preponderantly Diptera and Homoptera in Argentina (BASsO 1990). Hyla nana had a larger niche breadth for types and volume of prey in two ponds. The larger volume of the prey consumed by $H$. nana may be a consequence of its larger size, as observed for sympatric species of Urodela of the genus Bolitoglossa Duméril, Bribon, and Duméril, 1854 (ANDERson \& MathIs 1999).

The presence of a high percentage of empty stomachs in $H$. sanborni than $H$. nana may be related to differences in timing of feeding. Males of $H$. sanborni perhaps feed after calling or alternate feeding nights with calling nights, while $H$. nana perhaps feed before the beginning of calling activity. This fact could be corroborated by observations of males that not interrupted your vocal activity to feed insects that locomoved on or around them (D.C. Rossa-Feres, personal observation). The alternating between calling nights and feeding nights has been recorded for Physalaemus pustulosus (Cope, 1864) in Panama (RYAN 1985) and for three sympatric species of anurans in the United States (ANDERSON et al. 1999).

\section{Niche overlap and coexistence}

In general, the multidimensional overlap between $H$. nana and $H$. sanborni was wide, in disagreement with the theory of a limit of similarity between coexisting species (MACARTHUR \& Levins 1967). According to Abrams (1983), the idea of a universal limit is probably system specific, varying between species and environments. The intraspecific variation in resource use at the three water bodies, registered in the present study, reinforces this idea. On other hand, the wide overlap found can be a consequence of taxonomic relationships of these species. Related species share behavioral, physiological and morphological traits, because they are descendants of a common ancestor (Zimmerman \& SimberLof 1996).

The empirical approach to the ecological coexistence problem is embodied by resource partitioning studies; both make the assumption that communities are competitively structured (GORDON 2000). But other processes beyond interspecific competition, such as predation, parasitism, environmental variability and heterogeneity, set more important limits to the growth of natural populations (GORDON 2000) and coexistence of species. In addition, variations in the use of time, space and food result from two or more factors, such as competition, predation, morphological and physiological constraints (TofT 1985) and evolutionary history (Brooks \& McLennan 1991) which may operate independently, interactively or both (ToFT 1985). The wide niche overlap does not necessarily indicate competition, because if resources are not in short supply, two organisms can share them without detriment to one another (PIANKA 1974). 
Table VIII. Niche overlap (\%) between $H$. nana and H. sanborni along each niche dimension and the multidimensional overlap, at the three ponds (PP, PG e PT), Nova Itapirema, northwestern São Paulo, Brazil.

\begin{tabular}{cccccc}
\hline & \multirow{2}{*}{ Reproductive season } & \multirow{2}{*}{ Call site } & \multicolumn{2}{c}{ Diet } & \multirow{2}{*}{ Multidimensional overlap } \\
\cline { 4 - 5 } & & & Type of prey & Volume of prey & 58.8 \\
PP & 61.0 & 93.5 & 68.9 & 11.7 & 52.0 \\
PG & 36.4 & 62.4 & 87.2 & 21.7 & 62.6 \\
PT & 57.0 & 94.4 & 82.3 & 16.9 & \\
\hline
\end{tabular}

In this study, the data indicate that environmental structure, such as vegetation structure and hydroperiod directly influence the occurrence and the use of the resources used by these species. For example, the position and type of substrate used as a call site varied among the ponds, depending on the available vegetation. Because of this, the overlap in the use of the resources may be directly related to the degree of environmental heterogeneity.

Despite of the differences found in the trophic niche dimensions, there was wide overlap between $H$. nana and $H$. sanborni in the type of prey consumed. This fact might cause competition, if these resources were limited, or yet, could be a consequence of the level of identification of the prey. However, in natural assemblages of amphibians, food competition appears to be an unusual event, which plays a minor, or insignificant, role in the structure and dynamics of the assemblage, and has never been demonstrated in the field (KuzMIN 1995). Moreover, a wide overlap in diet was found for many sympatric species of anurans and skinks. However in all the following studies, the large food availability (MAC NALLY 1983, TwIGG et al. 1996), differences in microhabitat use (DIAZ \& VALENCIA 1985, Vrcibradic \& Rocha 1996, VitT et al. 2000) or the structural differences in habitats (McAlpine \& Dilworth 1989), permitted the coexistence of the species.

In conclusion, $H$. nana and $H$. sanborni of Nova Itapirema showed different relative abundance in distinct ponds, consumed prey of different size and probably fed at different periods. The data obtained suggest that the environmental structure, such as hydroperiod and vegetation structure, may change the dynamics of resource partition between these coexisting species. The coexistence of these species in the area seems to be conditioned, in some degree, to differences in major niche dimensions (reproductive season and diet), as well as the possibility that resources (arthropods and call sites) are not in short supply.

\section{ACKNOWLEDGEMENTS}

We would like to thank Elias F. L. Freitas, Rodrigo A. Silva and Francisco P. A. Filho for their help in the fieldwork. Kátia G. Facure helped in statistical analysis. Reinaldo J. F. Feres, Thiago J. Izzo, Gustavo Q. Romero and Mário A. Neto helped in the identification of some arthropods. Célio F. B. Haddad and Oswaldo Marçal Júnior provided useful comments. William E. Magnusson reviewed our English. Financial support was provided by CAPES to M. Menin.

\section{REFERENCES}

ABrams, P. 1983. The theory of limiting similarity. Annual Review of Ecology and Systematics, Palo Alto, 14: 359-376.

Aichinger, M. 1987. Annual activity patterns of anurans in a seasonal neotropical environment. Oecologia, Berlin, 71: 583-592.

Anderson, M.T. \& A. Mathis. 1999. Diets of two sympatric neotropical salamanders, Bolitoglossa mexicana and B. rufescens, with notes on reproduction for $B$. rufescens. Journal of Herpetology, St. Louis, 33 (4): 601-607.

Anderson, A.M.; D.A. Haukos \& J.T. Anderson. 1999. Diet composition of three anurans from the Playa Wetlands of Northwest Texas. Copeia, Lawrence, 1999 (2): 515-520.

ARID, F.M. \& S.F. BARCHA. 1973. Água subterrânea na formação Bauru - região Norte-ocidental do Estado de São Paulo. Boletim de Ciências da Faculdade de Filosofia, Ciências e Letras de São José do Rio Preto, São José do Rio Preto, 1: 70-101.

BAsso, N.G. 1990. Estrategias adaptativas en una comunidad subtropical de anuros. Cuadernos de Herpetologia, Serie Monografías, La Plata, 1: 1-70.

Basso, N.G.; S.I. Peri \& I.E. Di TADA. 1985. Revalidacion de Hyla sanborni, Schmidt, 1944 (Anura: Hylidae). Cuadernos de Herpetologia, Tucuman, 1 (3): 1-11.

BOWKer, R.G.; M.H. BowKer. 1979. Abundance and distribution of anurans in a Kenyan Pond. Copeia, New York, 1979 (2): 278-285.

Brooks, D.R.; D.A. McLennan. 1991. Phylogeny, ecology, and behavior: a research program in comparative biology. Chicago, The University of Chicago Press, 434p.

Cardoso, A.J.; G.V. Andrade \& C.F.B. Haddad. 1989. Distribuição espacial em comunidades de anfíbios (Anura) no sudeste do Brasil. Revista Brasileira de Biologia, Rio de Janeiro, 49 (1): 241-249.

Cardoso, A.J. \& J. Vielliard. 1990. Vocalizações de anfíbios anuros de um ambiente aberto, em Cruzeiro do Sul, Estado do Acre. Revista Brasileira de Biologia, Rio de Janeiro, 50 (1): 229-242.

Revista Brasileira de Zoologia 22 (1): 61-72, março 2005 
Colli, G.R.; A.F.B. Araújo; R. Silveira \& F. Roma. 1992. Niche partitioning and morphology of two syntopic Tropidurus (Sauria: Tropiduridae) in Mato Grosso, Brazil. Journal of Herpetology, Athens, 26 (1): 66-69.

Crump, M.L. 1974. Reproductive strategies in a tropical anuran community. Miscellaneous Publications of the Museum of Natural History, University of Kansas, Lawrence, 61: 168.

Crump, M.L. 1982. Amphibian reproductive ecology on the community level, p. 21-36. In: N.J. ScotT Jr. (Ed.). Herpetological communities. Washington, United Sates Department of the Interior, $239 \mathrm{p}$.

Diaz, N.F. \& J. VALENCIA. 1985. Microhabitat utilization by two leptodactylid frogs in the Andes of central Chile. Oecologia, Berlin, 66 (3): 353-357.

Digby, P.G.N. \& R.A. Kempton. 1987. Multivariate analysis of ecological communities. New York, Chapman and Hall, $216 \mathrm{p}$.

Donnelly, M.A. \& C. GuYer. 1994. Patterns of reproduction and habitat use in an assemblage of Neotropical hylid frogs. Oecologia, Berlin, 98: 291-302.

Duellman, W.E. 1970. The hylid frogs of Middle America. Monographs of the Museum of Natural History, University of Kansas, Lawrence, 1: 1-753.

Duellman, W.E. \& R.A. Pyles. 1983. Acoustic resource partitioning in anuran communities. Copeia, New York, 1983 (3): 639-649.

Etges, W.J. 1987. Call site choice in male anurans. Copeia, Gainesville, 1987 (4): 910-923.

Giller, P.S. 1984. Community structure and the niche. London, Chapman and Hall, 176p.

Gordon, C.E. 2000. The coexistence of species. Revista Chilena de Historia Natural, Santiago, 73 (1): 175-198.

Heyer, W.R.; A.S. Rand; C.A.G. Cruz; O.L. Peixoto \& C.E. Nelson. 1990. Frogs of Boracéia. Arquivos de Zoologia, São Paulo, 31 (4): 231-410.

HöDL, W. 1977. Call differences and calling site segregation in anuran species from Central Amazonian floating meadows. Oecologia, Berlin, 28: 351-363.

Krebs, C.J. 1999. Ecological Methodology. Menlo Park, Addison-Wesley Educational Publishers, $2^{\text {nd }}$ ed., 624p.

KuZmin, S.L. 1995. The problem of food competition in amphibians. Herpetological Journal, London, 5: 252-256.

LABANICK, G.M. 1976. Prey availability, consumption and selection in the cricket frog, Acris crepitans (Amphibia, Anura, Hylidae). Journal of Herpetology, Houston, 10 (4): 293298.

LANGONE, J.A. \& N.G. Basso. 1987. Distribucion geografica y sinonimia de Hyla nana Boulenger, 1889 y de Hyla sanborni Schmidt, 1944 (Anura, Hylidae) y observaciones sobre formas afines. Comunicaciones Zoológicas Del Museo de Historia Natural de Montevideo, Montevideo, 11 (164): $1-17$.
Lima, A.P. \& W.E. Magnusson. 1998. Partitioning seasonal time: interaction among size, foraging activity and diet in leaflitter frogs. Oecologia, Berlin, 116: 259-266.

Lizana, M.; V. Perez-Mellado \& M.J. Ciudad. 1990. Analysis of the structure of an amphibian community in the central system of Spain. Herpetological Journal, London, 1: 435446.

LOMAN, J. 1978. Macro- and microhabitat distribution in Rana arvalis and $R$. temporaria (Amphibia, Anura, Ranidae) during summer. Journal of Herpetology, Houston, 12 (1): 29-33.

MacArthur, R. \& R. Levins. 1967. The limiting similarity, convergence and divergence of coexisting species. American Naturalist, Chicago, 101 (921): 377-385.

Mac Nally, R.C. 1983. Trophic relationships of two sympatric species of Ranidella (Anura). Herpetologica, Lawrence, 39 (2): 130-140.

MAC NALly, R.C. 1985. Habitat and microhabitat distributions in relation to ecological overlap in two species of Ranidella (Anura). Australian Journal of Zoology, Collingwood, 33: 329-338.

MarTins, I.A. \& J. JiM. 2003. Bioacustic analysis of advertisement call in Hyla nana and Hyla sanborni (Anura, Hylidae) in Botucatu, São Paulo, Brazil. Brazilian Journal of Biology, São Carlos, 63 (3): 507-516.

McAlpine, D.F. \& T.G. Dilworth. 1989. Microhabitat and prey size among three species of Rana (Anura: Ranidae) sympatric in eastern Canada. Canadian Journal of Zoology, Ottawa, 67 (9): 2244-2252.

Oldham, R.S. \& H.C. Gerhardt. 1975. Behavioral isolating mechanisms of the treefrog Hyla cinerea and H. gratiosa. Copeia, New York, 1975 (2): 223-231.

Peltzer, P.M. \& R.C. Lajmanovich. 2000. Dieta de Hyla nana (Anura: Hylidae) en charcas temporarias de la llanura aluvial del río Paraná, Argentina. Boletín de la Asociación Herpetológica Española, Barcelona, 11 (2): 71-73.

Pianka, E.R. 1974. Niche overlap and diffuse competition. Proceedings of the National Academy of Science of USA, Washington, 71 (5): 2141-2145.

PianKA, E.R. 1975. Niche relations of desert lizards, p. 292-314.In: M. Cody \& J.M. Diamond (Eds). Ecology and evolution of communities. Cambridge, Harvard University Press, 560p.

PiANKA, E.R. 1994. Evolutionary ecology. New York, Harper Collins College Publishers, $5^{\text {th }}$ ed., 486p.

Pombal JR., J.P. 1997. Distribuição espacial e temporal de anuros (Amphibia) em uma poça permanente na Serra de Paranapiacaba, sudeste do Brasil. Revista Brasileira de Biologia, Rio de Janeiro, 57 (4): 583-594.

Putman, R.J. 1994. Community ecology. London, Chapman $\&$ Hall, 178p.

Rossa-Feres, D.C. \& J. Jim. 1994. Distribuição sazonal em comunidades de anfíbios anuros na região de Botucatu, São Paulo. Revista Brasileira de Biologia, Rio de Janeiro, 54 (2): 323-334.

Revista Brasileira de Zoologia 22 (1): 61-72, março 2005 
Rossa-Feres, D.C. \& J. Jim. 2001. Similaridade do sítio de vocalização em uma comunidade de anfíbios anuros na região noroeste do Estado de São Paulo, Brasil. Revista Brasileira de Zoologia, Curitiba, 18 (2): 439-454.

Ryan, M.J. 1985. The Túngara frog: a study in sexual selection and communication. Chicago and London, The University of Chicago Press, 230p.

Schoener, T.W. 1974. Resource partitioning in ecological communities. Science, Washington, 185: 27-39.

SoKAL, R.R. \& F.J. RohlF. 1979. Biometria: principios y métodos estadísticos en la investigación biológica. Madrid, $\mathrm{H}$. Blume Ediciones, 832p.

Tоғт, C.A. 1985. Resource partitioning in amphibians and reptiles. Copeia, Gainesville, 1985 (1): 1-21.

Twigg, L.E.; R.A. How; R.L. HatherLy \& J. Dell. 1996. Comparison of the diet of three sympatric species of Ctenotus skinks. Journal of Herpetology, Athens, 30 (4): 561-566.

VitT, L.J.; R.A. SouzA, S.S. Sartorius; T.C.S. Avila-Pires \& M.A. Espósito. 2000. Comparative ecology of sympatric Gonatodes (Squamata: Gekkonidae) in the western Amazon of Brazil. Copeia, Lawrence, 2000 (1): 83-95.

VRCibradic, D. \& C.F.D. Rocha. 1996. Ecological differences in tropical sympatric skinks (Mabuya macrorhyncha and Mabuya agilis) in southeastern Brazil. Journal of Herpetology, Athens, 30 (1): 60-67.

ZAR, J.H. 1999. Bioestatistical analysis. New Jersey, PrenticeHall, $4^{\text {th }}$ ed., 663p.

Zimmerman, B.L. \& D. Simberloff. 1996. An historical interpretation of habitat use by frogs in a Central Amazonian forest. Journal of Biogeography, Oxford, 23 (1): 27-46.

Received in 04.V.2004; accepted in 08.1.2005.

Revista Brasileira de Zoologia 22 (1): 61-72, março 2005 